Tersedia online di http://ejournal-balitbang.kkp.go.id/index.php/jp
e-mail:jurnalpari@gmail.com
Jurnal Pari
Volume 2 Nomor 2 Desember 2016
p-ISSN : 2502-0730
e-ISSN : 2549-0133

\title{
TERBITAN BIBLIOGRAFI SEBAGAI ALAT BANTU PENELUSURAN INFORMASI DI PERPUSTAKAAN PUSAT PENELITIAN SOSIAL EKONOMI KELAUTAN DAN PERIKANAN
}

\section{BIBLIOGRAPHY AS AN INFORMATION SEARCH TOOLS AT THE SOCIO ECONOMIC RESEARCH CENTER OF THE MARINE AND FISHERIES LIBRARY}

\author{
Siti Nurhayati; Arfah Elly * \\ ${ }^{*}$ Pusat Penelitian Sosial Ekonomi Kelautan dan Perikanan \\ Diterima tanggal : 14 Juni 2016 Diterima setelah perbaikan : 6 September 2016 \\ disetujui terbit : 31 Oktober 2016
}

\begin{abstract}
ABSTRAK
Bibliografi sangat penting bagi peneliti khususnya peneliti di Pusat Penelitian Sosial Ekonomi Kelautan dan Perikanan. Tujuan penulisan makalah memberikan gambaran pentingnya bibliografi dalam mendukun $\mathrm{g}$ tugas peneliti. Makalah ini menguraikan tentang pengertian dan definisi bibliografi jenis-jenis bibliografi, $s$ erta peranan bibliografi bagi peneliti. Peneliti perlu memahami biliografi ini untuk menunjukkan tentang keg iatan-kegiatan penelitian yang telah dan akan dilakukan oleh peneliti lain. Fungsi lain dari bibliografi adalah sebagai bagian dari jasa pelayanan perpustakaan kepada pemustaka. Dengan menerbitkan suatu bibliogr afi, pustakawan dapat menawarkan koleksinya kepada pemakai tanpa harus mengeluarkan seluruh koleks i yang dimilikinya, serta dapat menjangkau pemustaka yang tinggal jauh dari perpustakaan. Dengan demik ian maka, bibliografi dapat digunakan sebagai bahan rujukan terhadap koleksi perpustakaan. Selain itu dih arapkan dapat menjadi acuan bagi pengelola perpustakaan yang lainnya dalam meningkatkan kualitas lay anan kepada pemustaka khususnya peneliti.
\end{abstract}

Kata Kunci : bibliografi, peneliti, alat bantu

\begin{abstract}
The Bibliography is very important for researchers in particular those at the Marine and Fisheries for Socio-Economic Research Center. The purpose of writing this paper is to give an illustration of the importance of the bibliography to support the task of researchers. It describes the definition of bibliography, the types of bibliographic, as well as the role of bibliography for researchers. Researchers need to understand bibliography in order to show other researchers the research activities that have been and will be conducted. Another function of the bibliography is as a part of the library services to the patrons/users. By publishing a bibliography, librarians can offer their collection to the users without having to displaythe ir entire collection, and they can also reach those who are in remote places away from the library. Therefo re, the bibliography can be used as a reference material to the library collection as well as a reference for other library managers in improving the quality of their service to the patrons especially researchers
\end{abstract}

Keywords : Bibliography, researchers

Korespondensi Penulis :

Jl. Pasir Putih I Ancol Timur Lantai 3-4

Email : st.nurhayatinatsir@gmail.com 


\section{PENDAHULUAN}

Peneliti adalah bagian dari pembangunan kelautan dan perikanan karena hasil-hasil dari penelitiannya akan dapat menjadi rujukan bagi pengambil kebijakan. Salah satu institusi penelitian Kelautan dan Perikanan yaitu Pusat Penelitian Sosial Ekonomi Kelautan dan Perikanan (PPSEKP). Institusi ini merupakan ujung tombak pembangunan Kelautan dan Perikanan di Indonesia dalam hal pendayagunaan mengembangan kebijakan sumberdaya perikanan yang berkelanjutan dan berperspektif. Guna memenuhi harapan tersebut maka kegiatan penelitian terus ditingkatkan kualitasnya dengan cara pengkayaan informasi peneliti.

Dalam kegiatan penelitian, informasi menjadi kebutuhan yang sangat penting bagi para peneliti. Untuk itu peneliti harus mengetahui sumber- sumber informasi yang dibutuhkan. Salah satu caranya yaitu melalui penelusuran informasi. Penelusuran informasi adalah kegiatan untuk menghasilkan sebuah temuan atau informasi yang relevan, akurat dan tepat. Begitu juga proses dan penggunaan alat yang tepat akan menghasilkan informasi yang tepat pula. Dalam melakukan penelusuran diperlukan berbagai alat dan/atau sumber informasi antara lain bibliografi.

\section{TINJAUAN LITERATUR}

Pengertian bibliografi adalah publikasi yang memuat daftar dokumen baik yang "diterbitkan" dalam bentuk buku maupun artikel majalah atau bentuk kepustakaan lain yang berhubungan dengan bidang, ilmu pengetahuan atau hasil karya seseorang.

Peneliti dituntut untuk mengetahui informasi yang dimuat dalam bibliografi. Melalui bibliografi seorang peneliti akan mendapatkan informasi yang banyak untuk memulai suatu penelitian, disamping itu juga dapat menjadi bahan referensi. Bibliografi dapat menunjukkan tentang kegiatan-kegiatan penelitian yang dilakukan oleh peneliti lain. Dengan melihat bibliografi, tidak akan terjadi duplikasi atau pengulangan penelitian yang berakibat pada pemborosan anggaran dan juga dapat menghindari terjadinya plagiat. Bibliografi dapat dikelompokkan berdasarkan : bibliografi retrospektif yang mencatat bahan pustaka yang telah diterbitkan pada jaman yang lampau; bibliografi selektif yang mencatat terbitan tertentu dengan tujuan tertentu; dan bibliografi subjek yang mencatat bahan pustaka atau artikel pada bidang ilmu dan subjek tertentu. Bibliografi dibuat dengan tujuan mendaftar atau menyusun informasi mengenai buku serta bahan pustaka yang terkait dalam susunan logis dan bermanfaat. Karena untuk membantu pemakai dalam menentukan keberadaaan sebuah bahan pustaka atau mengenali sebuah buku yang populer. Fungsi Bibliografi bagi peneliti, mengetahui subjek apa saja yang telah ditulis untuk memperoleh informasi yang aktual, menghindarkan duplikasi penelitian. Sebagai sarana pemilihan buku (identitas, rincian bibliografi). Sarana untuk mengetahui perkembangan buku dan untuk memudahkan penggunan maka dibuatlah indeks pengarang, subjek dan tempat.

Bibliografi dalam kaitan kebutuhan informasi para pemustaka yang semakin beragam dan meningkat jumlahnya. Upaya untuk meningkatkan kualitas layanan penelusuran informasi yang cepat dan tepat oleh karena itu penyusunan suatu daftar bibliografi mempunyai fungsi utama untuk membantu pemustaka mencari dan menelusuri informasi tertentu. Fungsi lain dari bibliografi adalah sebagai bagian dari jasa pelayanan perpustakaan kepada pemakai. Dengan menerbitkan suatu bibliografi, pustakawan dapat menawarkan koleksinya kepada pemakai tanpa harus mengeluarkan seluruh koleksi yang dimilikinya, serta dapat menjangkau pengguna yang tinggal jauh dari perpustakaan. Dengan demikian maka, bibliografi dapat digunakan sebagai: Bahan rujukan terhadap koleksi perpustakaan. Tujuan dari tulisan ini adalah untuk menggambarkan penggunaan bibliografi hasil penelitian PPSEKP. 


\section{METODE}

Penulisan makalah ini dilakukan dengan melakukan studi literatur sekunder yang dianalisis secara deskriptif. Dalam studi pustaka diperoleh dari buku-buku mengenai perpustakaan, artikel jurnal, makalah/artikel online serta melalui artikel-artikel yang termuat dalam media cetak. Penulisan ini diawali dengan penentuan judul sesuai dengan topik yang telah di tetapkan, pengumpulan informasi untuk sumber literatur dan pembuatan konsep abstrak.

\section{HASIL DAN BAHASAN}

\section{Pengertian dan Definisi Bibliografi}

Pengertian bibliografi adalah publikasi yang memuat daftar dokumen baik yang "diterbitkan" dalam bentuk buku maupun artikel majalah atau bentuk kepustakaan lain yang berhubungan dengan bidang, ilmu pengetahuan atau hasil karya seseorang. Menurut Istilah bibliografi berasal dari kata yunani yaitu "biblion" dan "graphein". "Biblion" artinya buku sedangkan "grafein" artinya menulis. Jadi secara etimologis, bibliografi berarti penulisan buku (Palena, 2014). Dalam buku ini, bibliografi berarti teknik sistematik untuk membuat daftar deskriptif cantuman tertulis atau yang diterbitkan (terutama buku dan bahan pustaka sejenis). Maka bibliografi merupakan daftar yang dihasilkan dari kegiatan tersebut. (Sulistyo Basuki, 1991).

Secara definisi Bibliografi adalah publikasi yang memuat daftar dokumen baik yang "diterbitkan" dalam bentuk buku maupun artikel majalah atau bentuk kepustakaan lain yang berhubungan dengan bidang, ilmu pengetahuan atau hasil karya seseorang. Melalui bibliografi seseorang tidak menemukan dokumen pustakanya langsung, melainkan hanya memperoleh informasi tentang dokumen pustaka yang memuat informasi yang dicari. Data yang dicatat dalam bibliografi antara lain adalah nama pengarang, nama penyunting, judul pustaka, tempat terbit, tersebut, seperti informasi mengenai di dalam bahan pustaka apa informasi yang dicari berada. penerbit, tahun terbit dan edisi, volume, nomor, halaman (untuk majalah), serta keterangan fisik dokumen pustaka tersebut, misalnya jumlah halaman, tinggi buku, ilustrasi dsb. Dokumen pustaka yang terdaftar dalam bibliografi tidak perlu dijelaskan keberadaannya, yang penting bahwa dokumen tersebut ada karena pernah terbit.

Sarana bibliografi atau bibliographic tools adalah alat atau sarana yang digunakan untuk menemukan bibliografi. Bibliografi adalah semua daftar terbitan, baik yang tercetak atau yang terekam. Semua karya tulis secara konseptual dimaksudkan untuk dibaca oleh orang lain. Kumpulan dari karya tulis yang terbaca tersebut dapat membentuk akumulasi suatu pengetahuan. Karena itu, semakin banyak karya tulis yag terbaca, akan semakin kuat pula akumulasi pengetahuan itu. Pengetahuan itupun semakin tersebar sejalan dengan tersebarnya karya tulis. Sarana bibliografi berusaha untuk mencatat semua bahan pustaka yang pernah diterbitkan.

Dalam bentuk apapun diterbitkan dan dimanapun penerbitan dilakukan, hendaknya ada catatan tertulis mengenai sesuatu karya yang pernah diterbitkan. Seorang yang bekerja dalam bidang bibliografi akan berkutat dengan berbagai jenis terbitan dan tidak boleh membedakan kapan bahan pustaka itu diterbitkan. Terdapat sarana bibliografi yang mencatat bahan-bahan pustaka kuno, sebaliknya ada pula sarana bibliografi yang hanya mencatat bahan-bahan pustaka yang baru diterbitkan. Ada pula pembatasan bibliografi berdasarkan wilayah atau daerah dan ada pula bibliografi yang membatasi pada tahun terbit.

Penelusuran informasi di perpustakaan biasanya dilakukan dengan mengkompilasi beberapa jenis sarana bibliografi yang digunakan sebagai sarana penelusuran informasi. Jenis sarana bibliografi itu meliputi katalog, indeks, abstrak, bibliografi khusus, dan paket informasi. Seluruh sarana bibliografis tersebut disediakan bagi pengguna untuk melakukan penelusuran informasi serta sebagai alat bantu menemukan informasi dari dalam jajaran koleksi perpustakaan. 
Cara penggunaan sarana bibliografi berbeda-beda sesuai dengan sistem yang dipakai sarana tersebut. Hal ini telah dikuasai dan dipahami oleh para pemustaka perpustakaan yang telah menggunakan sarana online public access catalog (OPAC) dapat digunakan mencari informasi dengan cara pendekatan dan pencarian melalui kata kunci, indeks alfabetis, indeks klasifikasi (classified index), tajuk judul, dan tajuk pengarang. Untuk koleksi buku dan brosur akan dirujuk ke nomor panggilnya, sedang untuk koleksi majalah akan dirujuk ke judul dan kode lokasinya di tempat penyimpanan. Pada sarana bibliografi lain termasuk bibliografi khusus, suatu judul artikel atau informasi lain dirujuk ke buku atau majalah tempat artikel atau tulisan tersebut dimuat. Dengan demikian, sarana bibliografis sangat bermanfaat bagi pustakawan dalam melayani informasi untuk pengguna, yaitu sebagai alat temu kembali sumber informasi, alat bantu penelusuran informasi, dan wakil ringkas dari dokumen atau terbitan yang disimpan di koleksi (Sulistyo-Basuki 1991; Bandono 1995; Somadikarta 1998; Taylor 1999).

Sarana bibliografi bermanfaat untuk menelusur, mencari, dan menemukan informasi yang tercakup di dalam sarana tersebut. Pencarian sumber informasi atau judul artikel tertentu dilakukan melalui titik-titik akses yang tersedia pada setiap sumber informasi. Titik akses tersebut meliputi nomor panggil, judul, tajuk pengarang,subjek verbal atau notasi klasifikasi, dan kata kunci. Cara penelusuran informasi menggunakan titik akses adalah yang paling tepat dan cepat untuk menemukan sumber informasi yang dibutuhkan oleh para pengguna perpustakaan.

\section{Jenis-Jenis Bibliografi}

Jenis bibliografi yang dihasilkan dalam pembuatan publikasi sekunder akan tergantung pada jenis pustaka yang akan didaftar. Misalnya akan dibuat daftar yang berasal dari deskripsi katalog buku yang dimiliki perpustakaan, maka daftar tersebut dapat dinamakan daftar katalog. Sementara jika daftar yang disusun berdasarkan judul artikel suatu majalah, maka daftar tersebut dapat disebut daftar isi. Dari segi cara penyajian dan uraian deskripsinya, bibliografi dibagi menjadi: Bibliografi deskriptif: Yaitu bibliografi yang dilengkapi deskripsi singkat yang didapat dari gambaran fisik yang tertera atau tertulis dalam bahan pustaka. Seperti judul buku atau majalah, judul artikel, nama pengarang, data terbitan (impresium), kolasi serta kata kunci dan abstrak yang tertulis. Bibliografi evaluatif: yaitu bibliografi yang dilengkapi dengan evaluasi tentang suatu bahan pustaka. Evaluasi ini biasanya mencakup penilaian terhadap isi suatu bahan pustaka atau artikel. Dari segi cakupannya, bibliografi dapat dibagi menjadi: Bibliografi retrospektif : yaitu jenis bibliografi yang mencatat bahan pustaka yang telah diterbitkan pada jaman yang lampau. Misalnya Bibliografi sejarah perang Dipenogoro Bibliografi terkini/current : yaitu jenis bibliografi yang mencatat terbitan yang sedang atau masih terbit saat ini. Contohnya Ulrichâ International Periodicals Directory. Bibliografi selektif : yaitu jenis bibliografi yang mencatat terbitan tertentu dengan tujuan tertentu. Misalnya buku bacaan terpilih untuk anak usia pra sekolah. Bibliografi subjek : yaitu jenis bibliografi yang mencatat bahan pustaka atau artikel pada bidang ilmu dan subjek tertentu. Misalnya Bibliografi khusus Hasil Penelitian Sosial Ekonomi Kelautan dan Perikanan.

\section{Pengertian Penelusuran Informasi}

Ada beberapa pengertian mengenai penelusuran informasi, yaitu penelusuran informasi adalah kegiatan menelusur kembali atau sebagian informasi yang pernah ditulis atau diterbitkan melalui sarana temu-kembali informasi yang tersedia. (Purwono, 2012). Sedangkan menurut Suswanti (2012), penelusuran informasi atau temu kembali informasi adalah proses penemuan kembali informasi atau data yang di butuhkan pemakai yang telah disimpan dalam suatu sistem informasi atau dalam suatu pangkalan data. Jadi dapat disimpulkan, penelusuran informasi adalah kegiatan yang merupakan bagian dari temu kembali informasi yang dilakukan untuk mencari dan menemukan kembali informasi 
yang ada di dalam suatu pangkalan data melalui sarana yang tersedia

\section{Bibliografi Sosial Ekonomi Kelautan dan Perikanan}

Biliografi dan sarana bibliografis yang memuat tentang informasi sosial ekonomi kelautan dan perikanan telah banyak diterbitkan baik di dalam dan di luar negeri, dalam bentuk tulisan (paper) ataupun multimedia. Hal ini dapat digunakan oleh para peneliti sebagai sarana penelusuran informasi bidang sosial ekonomi kelautan dan perikanan. Selanjutnya akan diberikan contoh bibliografi dan saranan bibliografi, yang telah diterbitkan oleh perpustakaan Pusat Penelitian Sosial Ekonomi Kelautan dan Perikanan, seperti pada tabel berikut:
Bibliografi yang diterbitkan tersebut diatas sebagian besar merupakan hasil karya para pustakawan Pusat Penelitian Sosial Ekonomi Kelautan dan Perikanan. Penerbitan Bibliografi dan Kumpulan abstrak dibuat dalam rangka memudahkan pelayanan informasi bagi para peneliti. Informasi yang dimuat adalah hasil penelitian yang telah dipublikasikan dalam jurnal Penelitian yang diterbitkan oleh Pusat Penelitian Sosial Ekonomi Kelautan dan Perikanan.

Bibliografi dan kumpulan abstrak hasil penelitian dapat digunakan oleh peneliti sebagai acuan untuk bahan referensi penelitian atau juga penting untuk dapat mengetahui apakah

\section{DAFTAR BIBLIOGRAFI DAN SARANA BIBLIOGARFI YANG DITERBITKAN OLEH PERPUSTAKAAN PPSEKP}

\begin{tabular}{|c|c|c|c|c|c|}
\hline NO & JUDUL TERBITAN & PENYUSUN & $\begin{array}{l}\text { TAHUN } \\
\text { TERBIT }\end{array}$ & PENERBIT & KET \\
\hline 1 & $\begin{array}{l}\text { Katalog Koleksi } \\
\text { Perpustakaan edisi } 2007\end{array}$ & $\begin{array}{l}\text { Arfah Elly } \\
\text { Riesti T }\end{array}$ & 2009 & $\begin{array}{l}\text { Balai Besar Riset Sosial } \\
\text { Ekonomi Kelautan dan } \\
\text { Perikanan }\end{array}$ & \\
\hline 2 & $\begin{array}{l}\text { Bibliografi Hasil Penelitian } \\
\text { Sosial ekonomi kelautan } \\
\text { dan periknan 2002-2009 } \\
\text { Edisi } 1\end{array}$ & Arfah Elly & 2009 & $\begin{array}{l}\text { Balai Besar Penelitian } \\
\text { Sosial Ekonomi } \\
\text { Kelautan dan Perikanan }\end{array}$ & \\
\hline 3 & $\begin{array}{l}\text { Bibliografi Hasil Penelitian } \\
\text { Sosial ekonomi kelautan } \\
\text { dan perikanan 2009-2011 } \\
\text { Edisi } 2\end{array}$ & Arfah Elly & 2011 & $\begin{array}{l}\text { Balai Besar Penelitian } \\
\text { Sosial Ekonomi } \\
\text { Kelautan dan Perikanan }\end{array}$ & \\
\hline 4 & $\begin{array}{l}\text { Kumpulan Abstrak Jurnal } \\
\text { Penelitian Sosial Ekonomi } \\
\text { Kelautan dan Perikanan } \\
2002-2011\end{array}$ & $\begin{array}{c}\text { Arfah Elly, } \\
\text { Andokoro Yoga }\end{array}$ & 2012 & $\begin{array}{l}\text { Balai Besar Penelitian } \\
\text { Sosial Ekonomi } \\
\text { Kelautan dan Perikanan }\end{array}$ & \\
\hline 5 & $\begin{array}{l}\text { Abstracts of Journal Sosio- } \\
\text { Economics Marine and } \\
\text { Fisheries 2002-2011 }\end{array}$ & $\begin{array}{l}\text { Arfah Elly } \\
\text { Siti Nurhayati }\end{array}$ & 2013 & $\begin{array}{l}\text { Research center For } \\
\text { Marine and Fisheris } \\
\text { Socio Economics }\end{array}$ & \\
\hline 6 & $\begin{array}{l}\text { Bibiliogarfi Khusus Sosial } \\
\text { Ekonomi Kelautan dan } \\
\text { Perikanan Tahun } 2014\end{array}$ & $\begin{array}{l}\text { Arfah Elly } \\
\text { Siti Nurhayati }\end{array}$ & 2014 & $\begin{array}{l}\text { Balai Besar Penelitian } \\
\text { Sosial Ekonomi } \\
\text { Kelautan dan Perikanan }\end{array}$ & \\
\hline 7 & $\begin{array}{l}\text { Katalog Koleksi } \\
\text { Perpustakaan } 2014\end{array}$ & $\begin{array}{l}\text { Arfah Elly } \\
\text { Siti Nurhayati }\end{array}$ & 2014 & $\begin{array}{l}\text { Balai Besar Penelitian } \\
\text { Sosial Ekonomi } \\
\text { Kelautan dan Perikanan }\end{array}$ & \\
\hline 8 & $\begin{array}{l}\text { Abstarcs Science Direct } \\
\text { Social Economics } 2014\end{array}$ & $\begin{array}{l}\text { Arfah Elly } \\
\text { Siti Nurhayati }\end{array}$ & 2014 & $\begin{array}{l}\text { Balai Besar Penelitian } \\
\text { Sosial Ekonomi } \\
\text { Kelautan dan Perikanan }\end{array}$ & \\
\hline 9 & $\begin{array}{l}\text { Bibliografi Hasil Penelitian } \\
\text { Sosial ekonomi kelautan } \\
\text { dan perikanan 2011-2014 }\end{array}$ & $\begin{array}{c}\text { Arfah Elly, Siti } \\
\text { Nurhayati, Andakoro } \\
\text { Yoga Pratomo }\end{array}$ & 2015 & $\begin{array}{l}\text { Balai Besar Penelitian } \\
\text { Sosial Ekonomi } \\
\text { Kelautan dan Perikanan }\end{array}$ & \\
\hline
\end{tabular}




\begin{tabular}{clcclc}
\hline NO & JUDUL TERBITAN & PENYUSUN & $\begin{array}{l}\text { TAHUN } \\
\text { TERBIT }\end{array}$ & PENERBIT & KET \\
\hline 10 & $\begin{array}{l}\text { Kumpulan Abstrak } \\
\text { Jurnal Penelitian Sosial } \\
\text { Ekonomi Kelautan dan }\end{array}$ & Arfah Elly & 2015 & $\begin{array}{l}\text { Balai Besar Penelitian } \\
\text { Sosial Ekonomi } \\
\text { Kelautan dan Perikanan }\end{array}$ \\
$\begin{array}{l}\text { Perikanan 2011-2014 } \\
\text { Katalog Koleksi } \\
\text { Perpustakaan 2015 }\end{array}$ & Arfah Elly & 2015 & $\begin{array}{l}\text { Balai Besar Penelitian } \\
\text { Sosial Ekonomi } \\
\text { Kelautan dan Perikanan }\end{array}$ \\
\hline
\end{tabular}

penelitian yang akan dilakukan sudah dilakukan orang lain atau belum. Selain itu juga peneliti dapat mengetahui berapa banyak penelitian tentang komoditi Sosial Ekonomi kelautan dan perikanan tertentu sudah dilakukan, sehingga peneliti dapat mengembangkan penelitiannya lebih lanjut. Banyak manfaat atau kegunaan bibliografi diterbitkan untuk para peneliti seperti yang telah diuraikan diatas.

\section{Peranan Bibliografi bagi Peneliti}

Pembuatan bibliografi merupakan salah satu kegiatan perpustakaan yang dilakukan oleh pustakawan oleh karena itu sangat diperlukan kerjasama yang baik antara peneliti dan pustakawan agar dapat saling menguntungkan. Keuntungan bagi peneliti adalah bahwa informasi yang dibutuhkan akan dapat dilayani dengan baik oleh pustakawan. Bagi pustakawan juga akan sangat membantu untuk membuat bibliografi yang sesuai dengan permintaan para peneliti karena bagian yang terpenting dan tak terpisahkan dari sebuah perpustakaan adalah adanya proses temu kembali informasi, dimana secara spesifik juga akan menyangkut penelusuran informasi.

Temu kembali informasi sendiri merupakan kegiatan yang bertujuan untuk menyediakan dan memasok informasi bagi pengguna perpustakaan dan sebagai jawaban atas permintaan atau berdasarkan kebutuhan pengguna. "Temu balik informasi" merupakan istilah generik yang mengacu pada temu balik dokumen atau sumber atau data dari fakta yang dimiliki unit informasi atau perpustakaan. Sedangkan penelusuran informasi merupakan bagian dari sebuah proses temu kembali informasi yang dilakukan untuk memenuhi kebutuhan pengguna akan informasi yang dibutuhkan, dengan bantuan berbagai alat penelusuran dan temu kembali informasi yang dimiliki perpustakaan/unit informasi. Penelusuran informasi menjadi penting karena "ruh" atau "nyawa" dari sebuah layanan informasi dalam unit informasi atau perpustakaan adalah bagaimana memenuhi kebutuhan informasi yang diminta pemakai, bagaimana menemukan informasi yang diminta pemakai, dan bagaimana memberikan "jalan" kepada pemakai untuk menemukan informasi yang dikehendaki. (Rufaidah,VW,1998).

Berdasarkan uraian diatas, bibliografi merupakan alat penelusuran informasi yang sangat penting untuk para peneliti karena dalam bibliografi dimuat beberapa informasi yang diperlukan untuk referensi bahan penelitian. Disamping itu juga, dalam satu bibliografi dapat diperoleh informasi tertentu dalam bidang tertentu, hal ini sangat membantu bagi para peneliti untuk mengetahui status penelitian yang akan dilakukan. Jika sudah pernah ada yang melakukan berarti seorang peneliti akan dapat menghindari duplikasi penelitian dan sekaligus dapat mencegah terjadinya pemborosan anggaran.

Dengan adanya bibliografi, para peneliti sangat terbantu untuk menginventarisir tulisantulisanya yang pernah diterbitkan untuk dapat dimanfaatkan oleh peneliti lain dan sebagai 
bukti sejarah bahwa tulisan pernah diterbitkan oleh majalah atau penerbitan ilmiah yang lain. Dengan demikian melalui bibliografi para peneliti selain dapat menelusur informasi dengan mudah juga dapat membantu para peneliti menyebarkan informasi hasil penelitianya untuk didayagunakan bagi yang memerlukan. Peranan bibliografi bagi peneliti dari uraian diatas antara lain untuk memudahkan mencari informasi yang diperlukan, menghindari terjadinya duplikasi penelitian, dan menyebar luaskan serta mendayagunakan informasi hasil penelitian yang telah dilakukan kepada para pengguna.

\section{KESIMPULAN DAN SARAN}

Berdasarkan uraian tersebut dapat disimpulkan bahwa bibliografi dan sarana bibliografi sangat penting dan bermanfaat bagi para peneliti. Begitu juga untuk para pemustaka lainnya baik di lingkup Kementerian Kelautan dan Perikanan juga di luar Kementerian Kelautan dan Perikanan. Tujuan utama dalam pembuatan sarana bibliografi adalah merupakan penghubung antara kebutuhan informasi pemustaka, khususnya peneliti dan sumber informasi yang ada karena Bibliografi merupakan kegiatan teknis membuat deskripsi untuk suatu cantuman tertulis atau pustaka yang telah di terbitkan, yang di susun secara sistematis beupa daftar memuat aturan yang di kehendaki. Dengan bibliografi ini seseorang mengetahui adanya suatu buku/pustaka atau sejumlah buku/pustaka yang pernah di terbitkan. Dengan demikian komunikasi yang baik antara peneliti dan pustakawan sangat diperlukan guna meningkatkan kualitas pelayanan informasi di perpustakaan. Para pustakawan juga harus selalu berupaya memperluas titik-titik akses atau subyek tertentu yang disediakan dalam sarana bibliografi sehingga peneliti makin mudah melakukan penelusuran informasi serta makin cepat menemukan informasi yang diinginkan. Penggunaan sarana bibliografis oleh pustakawan menunjukkan berjalannya fungsi layanan perpustakaan, yang berarti kualitas layanan juga turut ditentukan oleh kualitas sarana bibliografi yang tersedia. Untuk itu, disarankan kepada para peneliti sebagai pemustaka utama perpustakaan Pusat Penelitian Sosial Ekonomi Kelautan dan Perikanan, agar dapat memberikan masukan dan menjalin kerjasama yang baik dengan pustakawan supaya dapat mengembangkan dan mengelola jenis-jenis sarana bibliografis yang sesuai dengan kebutuhan para peneliti, khususnya yang berkaitan dengan bidang Sosial Ekonomi Kelautan dan Perikanan.

\section{DAFTAR PUSTAKA}

Mustafa, Badolahi dan Rahman Saleh. Abdul . 1994. Bahan Rujukan Umum. Yogyakarta:

Palena,Gus;2016.http://guspalenatiolen.blog spot.co.id/2012/04/pengertian-bibliografidan-jenisnya.html?show Comment $=1396789188758 \# c 82360276376$ 3671202 Diakses pada Tanggal 30 April 2016, jam 11.32

Purwono; Temu Kembali Informasi Bibliografi dengan bahasa alami pada file judul dan subjek (Studi Efektifitas katalog induk terpasang perpustakaan UGM): Jurnal Berkala IImu Perpustakaan dan Informasi Volume III No. 1, 2006

Rufaidah,VW.,1988. Peranan Bibliografi Nasional Indonesia (BNI) dalam Pengawasan Bibliografi di Era Teknologi Informasi. Jurnal Pustakawan Indonesia Vol. No.7.

Sulistyo-Basuki. 1991. Pengantar Ilmu Perpustakaan. Gramedia Pustaka. Jakarta.

Suwanti, Sri Ati. 2015. Temu Kembali informasi dari sudut pandang pendekatan berorientasi pemakai

Triani, S. 2006. Pemanfaatan Sarana Bibliografis Oleh Pustakawan. Jurnal Perpustakaan Pertanian Vol. 15, Nomor 2.

Yusuf, Pawit M. 1988. Pedoman mencari sumber informasi. Bandung: Remadja Karya 